\title{
Dynamics of heterotrophic bacteria attached to Microcystis spp. (Cyanobacteria)
}

\author{
Jakob Worm ${ }^{1, *}$, Morten Søndergaard ${ }^{2}$ \\ ${ }^{1}$ Section of Genetics and Microbiology, Department of Ecology and Molecular Biology, The Royal Veterinary and \\ Agricultural University, Thorvaldsensvej 40, DK-1871 Frederiksberg C, Denmark \\ ${ }^{2}$ Freshwater Biological Laboratory, University of Copenhagen, Helsingørsgade 51, DK-3400 Hillerød, Denmark
}

\begin{abstract}
We studied the ecology of heterotrophic bacteria attached to the mucilaginous colonies of Microcystis spp. (Cyanobacteria) in the eutrophic lake Frederiksborg Slotssø, Denmark. The succession in bacterial abundance, production and potential aminopeptidase activity in $20 \mu \mathrm{m}$ fractionated samples was followed during periods in which Microcystis dominated the phytoplankton. We operationally defined that nets of $20 \mu \mathrm{m}$ mesh-width segregated bacteria associated with Microcystis (Microcystisassociated bacteria, $M B_{;}>20 \mu \mathrm{m}$ size fraction) from the mainly free-living bacteria in the filtrate ( $F B$, $<20 \mu \mathrm{m}$ size fraction). According to this definition, the contribution of MB during summer 1995 and autumn 1994, respectively, averaged $10 \pm 4$ ( \pm standard deviation) and $37 \pm 12 \%$ of total bacterial biomass and $25 \pm 13$ and $43 \pm 16 \%$ of total bacterial production, as estimated from thymidine (TdR) incorporation. During summer, $\mathrm{MB}$ further contributed $55 \pm 18 \%$ of total leucine incorporation measured at $600 \mathrm{nM}$ leucine and $53 \pm 12 \%$ of total potential aminopeptidase activity. Although $20 \mu \mathrm{m}$ mesh-width nets also retained particles other than Microcystis, our results indicate that Microcystis was a 'hotspot' for bacterial activity, comparable to larger aggregates known as marine or lake snow. During summer, growth rate and specific aminopeptidase activity of $M B$ generally exceeded those of $F B$, which points to diversifjed microenvironments or species compositions. In order to balance gain and loss rates within the community of $\mathrm{MB}$, we hypothesize that a large fraction of $\mathrm{MB}$ produced were exported from Microcystis to the surrounding water, only modified by the loss due to viral lysis. This idea arose from reported low loss rates of Microcystis and continuous measures indicating that a surplus of more than $70 \%$ of $\mathrm{MB}$ production (TdR) was not reflected as biomass increases within the community of $\mathrm{MB}$. According to this hypothesis Microcystis may be considered as a bacterial 'incubator' for the surrounding water.
\end{abstract}

KEY WORDS: Attached bacteria Microcystis - Eutrophic lake - Microhabitat

\section{INTRODUCTION}

The cyanobacterium Microcystis is a common genus in eutrophic lakes and often dominates the phytoplankton during summer and autumn. Microcystis forms large $(>1.00 \mu \mathrm{m})$ mucilaginous colonies usually colonized by (heterotrophic) bacteria (Whitton 1973). Bacteria associated with Microcystis are hypothesized to live in a microhabitat distinct from the surrounding water, because the microscale physicochemical environment is influenced by the particulate nature of Microcystis and the metabolism of the autotrophic and heterotrophic organisms present.

•E-mail: jaw@kvl.dk
In general, large particles in aquatic systems are colonized by bacteria at densities exceeding the surrounding water on a per volume basis; however, attached bacteria usually contribute less than $10 \%$ of total bacterial abundance (Kirchman 1993). Particles are argued to be favourable microenvironments compared to the surrounding water, because availability of potential substrates to bacterial growth is facilitated by organic components of particles, adsorbed matter, and, possibly, an increased flux of dissolved nutrients during sinking (reviewed by Fletcher 1991, Kirchman 1993). Further, Herndl (1988) suggested that shortcircuit nutrient cycles may form when autotrophic and heterotrophic organisms are closely associated in particulate matter (marine snow), thus increasing the 
regenerative power and, potentially, the overall microbial activity

Microcystis is a distinct bacterial microhabitat compared to a detrital particle, because the attached bacteria are closely associated with the principal producer of organic carbon for bacterial growth. The potential for microenvironmental conditions is demonstrated as elevated $\mathrm{pH}$ within the mucilage of axenic photosynthesizing Microcystis colonies (Richardson \& Stolzenbach 1995). Respiring bacteria counteract the chemical changes in $\mathrm{O}_{2}, \mathrm{CO}_{2}$ and $\mathrm{pH}$ induced by photosynthesis and a mutualistic relationship between cyanobacteria and associated (heterotrophic) bacteria has frequently been suggested (Whitton 1973), but to our knowledge no studies have yet evaluated the diffusive regime of Microcystis including attached bacteria. Intracellular gas vacuoles enable Microcystis to ascend the water column at speeds up to $3.2 \mathrm{~m} \mathrm{~d}^{-1}$ (Reynolds 1973, Reynolds \& Rogers 1976), which prevents sedimentation and increases the exchange of nutrients with the water surrounding the colonies. The buoyancy is counterbalanced by accumulated carbohydrates during photosynthesis, and to some extent the diel light cycle drives vertical up and down migrations (Thomas \& Walsby 1986). Loss of Microcystis from the water column is also reduced, because grazing by zooplankton is inhibited by the colony size and a potential toxicity from intracellular microcystin (DeMott \& Dhawale 1995). Similarly, mesozooplankton has been shown not to ingest bacteria attached to Microcystis (Bern 1987) and bacteria embedded in mucilage may be protected from protozoan ingestion (Jürgens \& Güde 1994). Gradually during autumn, however, Microcystis disappears from the pelagic waters and sinks to the sediment (Boström et al. 1989), because low temperature inhibits the ability to regain buoyancy (Thomas \& Walsby 1986).

A few studies have estimated the relative contribution of bacteria attached to Microcystis in eutrophic lakes. Bacteria attached to Microcystis accounted for 6 to $40 \%$ of total bacterial abundance during 3 sampling days and from 7 to $30 \%$ of total bacterial production during a diel study in Lake Vallentjunasjön, Sweden (Brunberg 1993). Less specific for Microcystisassociated bacteria, 15 to $33 \%$ of the bacterioplankton was retained in the $>5 \mu \mathrm{m}$ pore-size fraction during a 2 yr study in a Japanese pond (Konda 1984) and $>50 \%$ of bacterial production was associated with $>3 \mu \mathrm{m}$ pore-size fractions in Lake Norrviken, Sweden (Bell et al. 1983). Thus, bacteria attached to Microcystis may contribute significantly to pelagic bacterial carbon dynamics.

We aimed to study the ecology of Microcystis-associated bacteria (MB) based on successive and physiological parameters in comparison with the rest of the pelagic bacterial community (mainly free-living bacte- ria, FB). We operationally defined that $20 \mu \mathrm{m}$ meshwidth nets separated $\mathrm{MB}(>20 \mu \mathrm{m})$ and $\mathrm{FB}(<20 \mu \mathrm{m})$ to make it feasible to obtain continuous measures of bacterial abundance and activity. Based upon this, the microhabitat of $\mathrm{MB}$ is characterized as a 'hotspot' for bacterial activity with overall significance in bacterial carbon processing and population dynamics during blooms of Microcystis.

\section{MATERIALS AND METHODS}

Study site. The study was carried out in Frederiksborg Slotssø, Denmark, during autumn 1994 and summer 1995. The lake (mean depth: $3.1 \mathrm{~m}$ ) is highly eutrophic with a dense bloom of colony forming cyanobacteria during summer and autumn, when chlorophyll concentrations may exceed $100 \mu \mathrm{g} \mathrm{l}^{-1}$ (Andersen \& Jacobsen 1979, Christoffersen et al. 1990).

Sampling. Water from 0 and $0.5 \mathrm{~m}$ depth was taken from the middle of the lake and mixed in equal volumes either at noon (autumn) or in the morning (summer).

Subsamples of $10 \mathrm{ml}$ for bacterial abundance and activity were fractionated with $20 \mu \mathrm{m}$ mesh-width $25 \mathrm{~mm}$ nets (Nitex). We operationally defined that bacteria attached to Microcystis (MB) dominated the $>20 \mu \mathrm{m}$ size fraction in abundance and activity and that bacteria in the filtrate $(\mathrm{FB},<20 \mu \mathrm{m}$ size fraction) mainly originated from the water phase. The $20 \mu \mathrm{m}$ mesh-width net retained $98 \%$ of the Microcystis colonies. No further attempts were made to quantify detachment of $\mathrm{MB}$ during fractionation and the contribution of bacteria attached to other particles than Microcystis in the $>20 \mu \mathrm{m}$ size fraction.

Bacterial biomass. MB collected on $20 \mu \mathrm{m}$ meshwidth nets were transferred to $0.2 \mu \mathrm{m}$ prefiltered Milli$\mathrm{Q}$ water and processed as the filtrate. Samples were fixed with glutaraldehyde $(1.2 \%$ final concentration) and stored at $4^{\circ} \mathrm{C}$ for 3 to 4 mo (autumn) or 0.5 to 2 mo (summer). Recent studies have demonstrated that storage for several weeks can reduce bacterial number and cell volume distribution (Turley \& Hughes 1992 Gundersen et al. 1996). Effects of storage were not accounted for in the proscnt study. Bacteria associated with particles and the walls of storage containers were detached by 2 min of sonication with a Branson Sonifier 250 adjusted to $50 \%$ duty cycle and $306 \mu \mathrm{m}$ amplitude (25 W) (Velji \& Albright 1993). No effect of sonication was observed on bacterial abundance in $3 \mu \mathrm{m}$ pore-size filtrates (data not shown). Bacteria were quantified by direct microscopic counting of DAPIstained (4',6-diamidino-2-phenylindole, Sigma final concentration $0.1 \mu \mathrm{g} \mathrm{ml}^{-1}$ ) bacteria collected on $0.2 \mu \mathrm{m}$ pore-size black polycarbonate filters (Porter \& Feig 
1980). Bacterial cell volumes were calculated from measured length/widths or diameters from enlarged micrographs. Cell volumes were converted to cell carbon by the factor $105 \mathrm{fg} \mathrm{C} \mathrm{mm}^{-3}$ (Theil-Nielsen \& Søndergaard in press), as the bacterial volumes used to calculate this factor were estimated with similar equipment and methods.

Bacterial production. Bacterial production was estimated from the incorporation of $\left[{ }^{3} \mathrm{H}\right]$-thymidine (TdR) into DNA (Fuhrman \& Azam 1980) and during summer was also from $\left[{ }^{3} \mathrm{H}\right]$-leucine (Leu) incorporation into proteins (Kirchman et al. 1985). Incorporation rates were measured at substrate saturation concentrations estimated from kinetic experiments before each sampling for TdR incorporation and 4 times during summer for Leu incorporation.

Triplicate samples and 1 blank were incubated at in situ conditions for $1 \mathrm{~h}$ with $\left[\right.$ methyl- $\left.{ }^{3} \mathrm{H}\right]$-thymidine (Amersham) diluted to $20 \mathrm{nM}\left(10 \mathrm{Ci} \mathrm{mmol}{ }^{-1}\right)$ and $\mathrm{L}-[4,5-3 \mathrm{H}]$-leucine (Amersham) diluted to $600 \mathrm{nM}$ (1 $\mathrm{Ci} \mathrm{mmol}{ }^{-1}$ ) final concentrations. Incorporation was stopped by adding $100 \%$ trichloroacetic acid (TCA) to a final concentration of 5\%. TCA was added to the blanks prior to the incubations. Radiolabeled macromolecules were extracted for $1 \mathrm{~h}$ at $4^{\circ} \mathrm{C}$ before the samples were fractionated with $20 \mathrm{\mu m}$ mesh-width nets. The $20 \mu \mathrm{m}$ mesh-width nets, retaining ${ }^{3} \mathrm{H}$ incorporated by $\mathrm{MB}$, were placed on $0.4 \mu \mathrm{m}$ pore-size cellulose-nitrate membrane filters (Micro Filtration System), similar to the filters used to collect bacteria from the filtrates. Filters were rinsed with cold 5\% TCA $(\times 4)$ and $80 \%$ ethanol $(\times 2)$ (Wicks \& Robarts 1988 , Hollibaugh \& Wong 1992 ) and radioactivity was quantified with an LKB Wallac 1219 Rackbeta liquid scintillation counter.

Thymidine incorporation was converted to cell production with the factor $2 \times 10^{18}$ cells $\mathrm{mol}^{-1}$, which has previously been estimated for Frederiksborg Slotss $\theta$ (Smits \& Riemann 1988) and another eutrophic lake (Bell et al. 1983). Carbon production was derived from cell production by the average cell carbon specified for each fraction. Leucine incorporation was converted

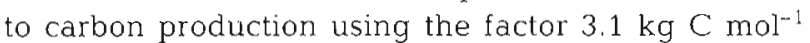
(Simon \& Azam 1989). Exponential growth rates were calculated to relate bacterial production and biomass.

Aminopeptidase activity. The potential aminopeptidase activity was measured with the fluorogenic model substrate L-leucine-4-methyl-coumarinylamid hydrochloride (Leu-MCA) according to Hoppe (1993).

$\mathrm{MB}$ collected on $20 \mu \mathrm{m}$ mesh-width nets were resuspended in $0.2 \mu \mathrm{m}$ sterile filtered lake water and processed as the filtrate. Triplicate samples were incubated with Leu-MCA (Sigma) at $0.2 \mathrm{mM}$ final concentration (saturation level) in the dark at in situ temperature. After $1 \mathrm{~h}$ incubation, Leu-MCA was added to blank samples and fluorescing hydrolysates were quantified subsequently with a spectrofluorophotometer (Shimadzu RF-5001PC). From August 3 to 17 samples had to be stored until later quantification (less than 3 wk at $-18^{\circ} \mathrm{C}$ ). After incubation and Leu-MCA addition to the blanks, samples were filter sterilized $10.45 \mu \mathrm{m}$ cellulose-nitrate membrane filters, Micro Filtration System) to minimize the hydrolysis from particle bound enzymes during freezing and thawing and stored at $-18^{\circ} \mathrm{C}$. Two later experiments showed that sterile filtration upon incubation reduced fluorescence by 26 and $62 \%$. Stored samples are therefore corrected by an average factor of 1.99 and excluded from statistical analysis and other concluding calculations.

Chlorophyll, POC, DOC. Chlorophyll was collected on Whatman GF/C filters, extracted with $96 \%$ ethanol overnight and measured spectrophotometrically (Jespersen \& Christoffersen 1987). Particulate organic carbon (POC) and dissolved organic carbon (DOC) were separated by filtration with precombusted $\left(550^{\circ} \mathrm{C}\right)$ $13 \mathrm{~mm} \mathrm{GF} / \mathrm{F}$ filters. POC was measured as $\mathrm{CO}_{2}$ emitted from combustion of filters $\left(600^{\circ} \mathrm{C}\right)$ by use of an infrared gas analyser (Sondergaard \& Middelboe 1993) and DOC was measured by a Pt-catalytic carbon analyser (Shimadzu TOC-5000).

Statistical analysis. Equivalence of $\mathrm{MB}$ and $\mathrm{FB}$ in growth rates and specific aminopeptidase activity were tested nonparametrically with the Wilcoxon signed rank test. Spearman rank correlation coefficients $\left(r_{s}\right)$ were calculated to test patterns among variables, unless other calculations are mentioned. In the kinetic experiments, leucine incorporations at the respective concentrations were fitted to the Michaelis-Menten equation of enzyme kinetics by the least squares estimation of the parameters $V_{\max }$ and $K_{\mathrm{m}}$. Randomness of data points relative to fitted lines were confirmed with Runs test and Sign test and equivalence of $K_{n}$ values were compared with $t$-tests. The level of significance was 0.05

\section{RESULTS}

Kinetic experiments showed that thymidine (TdR) incorporation was saturated at $20 \mathrm{nM}$, whereas leucine (Leu) incorporation never saturated below $200 \mathrm{nM}$. The Michaelis-Menten equation of enzyme kinetics was fitted to the saturation curves of Leu incorporation with values of $r^{2}$ between 0.78 and 0.99 . All values of $K_{\mathrm{m}}$ were higher in the $>20 \mu \mathrm{m}$ size fraction compared to the $<20 \mu \mathrm{m}$ size fraction, although this difference was statistically significant in only 2 of 3 comparisons, i.e. on July 26 and August 1. Leu incorporation in the $>20 \mu \mathrm{m}$ size fraction, assigned to $\mathrm{MB}$, therefore showed less affinity and saturated at higher concentrations compared to the $<20 \mu \mathrm{m}$ size fraction, domi- 


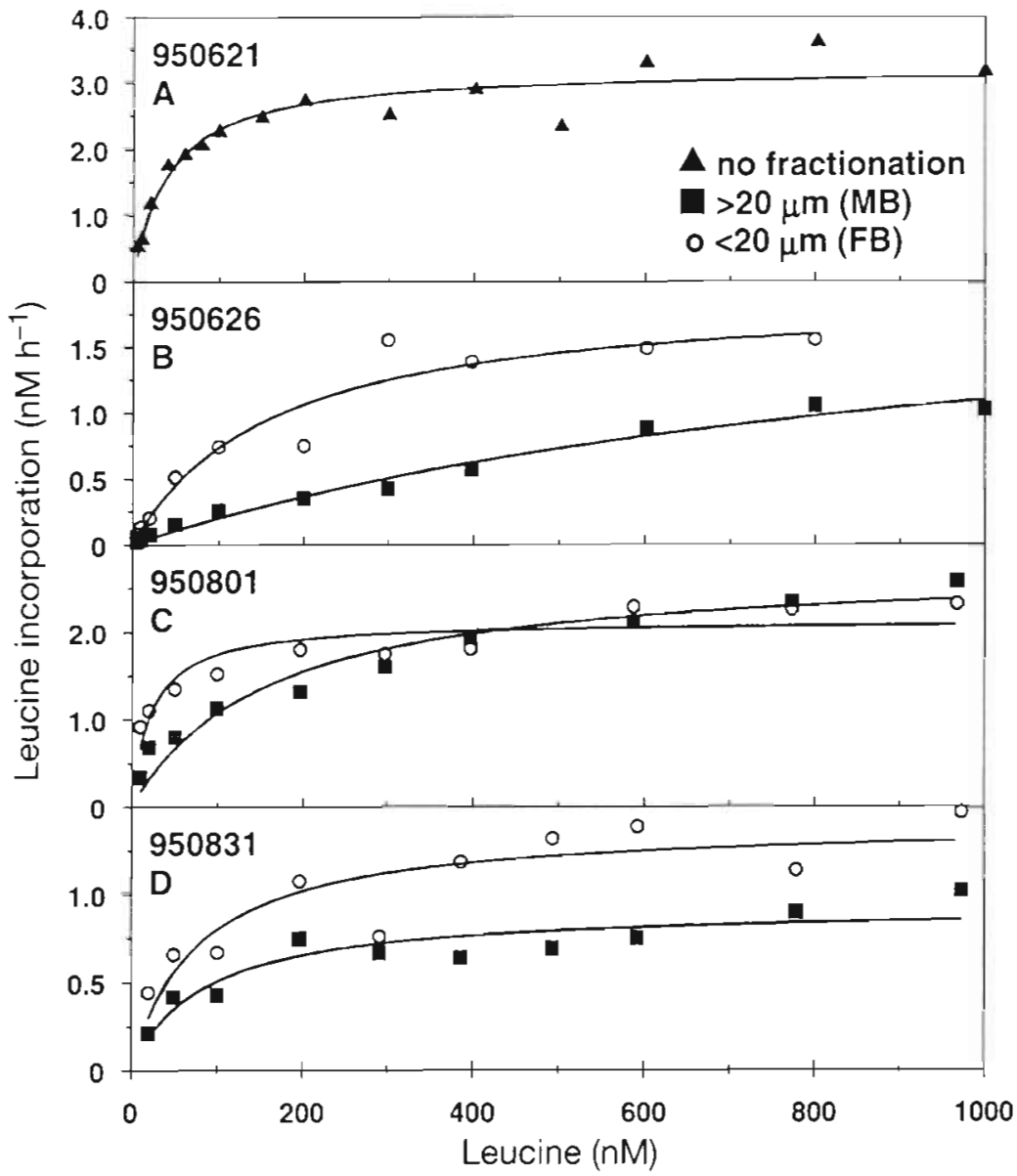

Fig. 1. Kinetics of leucine incorporation fitted to the Michaelis-Menten equation of enzyme kinetics with values of $r^{2}$ from 0.78 to 0.99 . (A) No fractionation (B-D) MB designates $>20 \mu \mathrm{m}$ size fractions, presumed to be dominated by Microcystis-associated bacteria, and FB designates $<20 \mu \mathrm{m}$ size fractions dominated by mainly free-living bacteria nated by $F B$. Leu incorporation at $600 \mathrm{nM}$, the concentration used to estimate bacterial production, tended to saturate (Fig. 1). Most estimates of $K_{\mathrm{m}}$ ranged from 21 to $164 \mathrm{nM}$, corresponding to 97 and $79 \%$ saturation at $600 \mathrm{nM}$ according to the Michaelis-Menten equation. The exception was $\mathrm{MB}$ on June 26, where $K_{\mathrm{m}}=1016 \mathrm{nM}$, corresponding to only $37 \%$ saturation.

Results from summer 1995 and autumn 1994 are presented in succession according to seasons rather than chronology, because general patterns of bacterial growth dynamics are assumed to be reflected (Fig. 2). Chlorophyll and POC were positively correlated $\left(\mathrm{r}_{\mathrm{s}}>\right.$ 0.75, p < 0.007) and Microcystis spp. dominated the phytoplankton during both seasons.

$\mathrm{MB}$ increased in biomass from $8 \mu \mathrm{g} \mathrm{C}$ $\mathrm{I}^{-1}$ in early July to a maximum value of $15.9 \mu \mathrm{g} \mathrm{Cl}^{-1}$ on August 7 and afterwards declined gradually to $5.3 \mu \mathrm{g} \quad \mathrm{C}^{-1}$ (Fig, 2). In parallel, MB production (TdR) increased from $\mathrm{Ca} 0.25$ to $3.77 \mu \mathrm{g} \mathrm{C} \mathrm{l} \mathrm{C}^{-1}$ $\mathrm{h}^{-1}$ on August 3 and decreased steadily to $0.79 \mu \mathrm{g} \mathrm{C} \mathrm{l}^{-1} \mathrm{~h}^{-1}\left(\mathrm{r}_{\mathrm{s}}=0.80, \mathrm{p}=0.003\right.$, $\mathrm{n}=15$ ). Similar trends were measured from leucine incorporation at $600 \mathrm{nM}$ $\left(\mathrm{r}_{\mathrm{s}}=0.73, \mathrm{p}=0.008, \mathrm{n}=14\right)$ and converted to production (Leu) the estimates were 4 -fold higher than calculated from the TdR method. Production also corre-

Table 1. Spearman rank correlation coefficients $\left(\mathrm{r}_{\mathrm{s}}\right)$ between parameters for Microcystis-associated bacteria (MB, size fraction $>20 \mu \mathrm{m}$ ) and bacteria living in the surrounding water (FB, size fraction $<20 \mu \mathrm{m})$. Levels of significance are indicated with asterisks: $\cdots p<0.001, \cdots p<0.01, \quad p<0.05 .-: p>0.05$

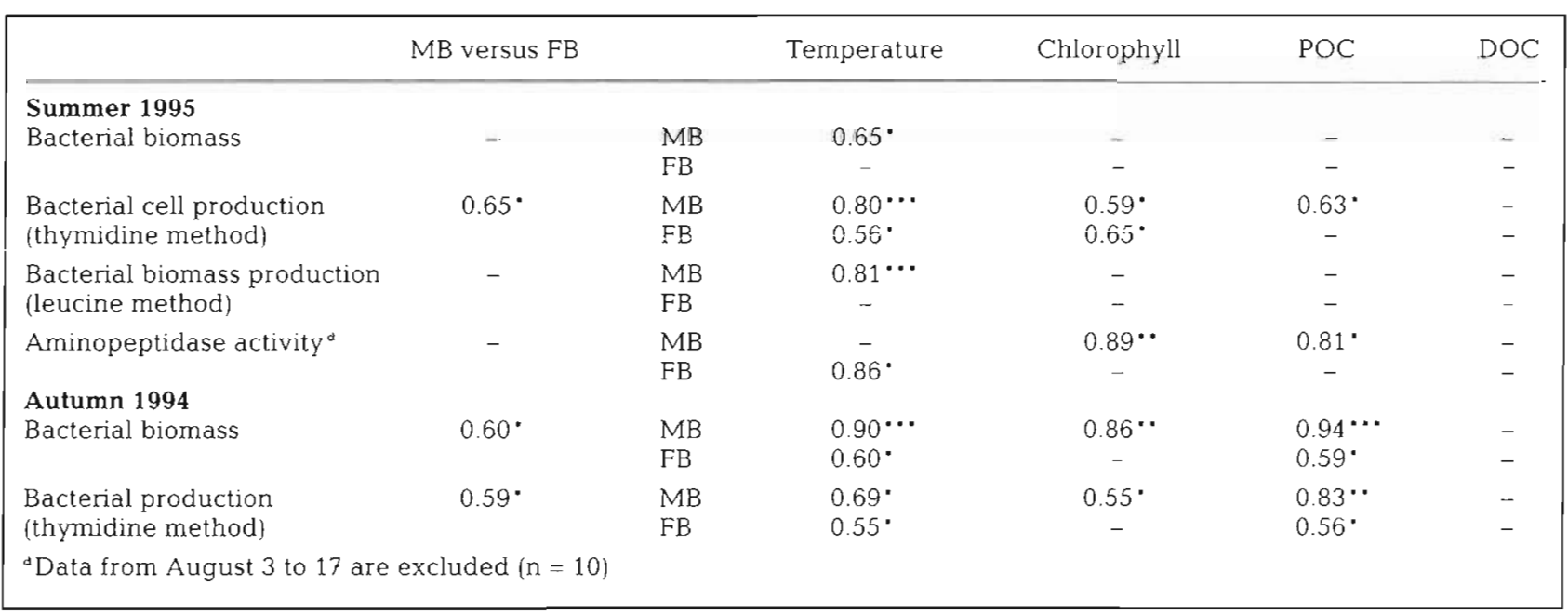


Fig. 2. Continuous measures of abiotic, algal and bacterial parameters, Frederiksborg Slotss $\varnothing$, summer 1995 and autumn 1994. (-) Microcystis-associated bactena ( $M B,>20 \mu m$ mesh-width size fraction) and ( 0 ) bacteria in the surrounding water $(\mathrm{FB},<20 \mu \mathrm{m}$ mesh-width size fraction). Error bars indicate standard deviation of triplicate samples of dissolved organic carbon (DOC), particulate organic carbon (POC), bacterial production and aminopeptidase activity. Aminopeptidase from August 3 to 17 are multiplied by 1.99 to correct for fluorescence lost during sterile filtration

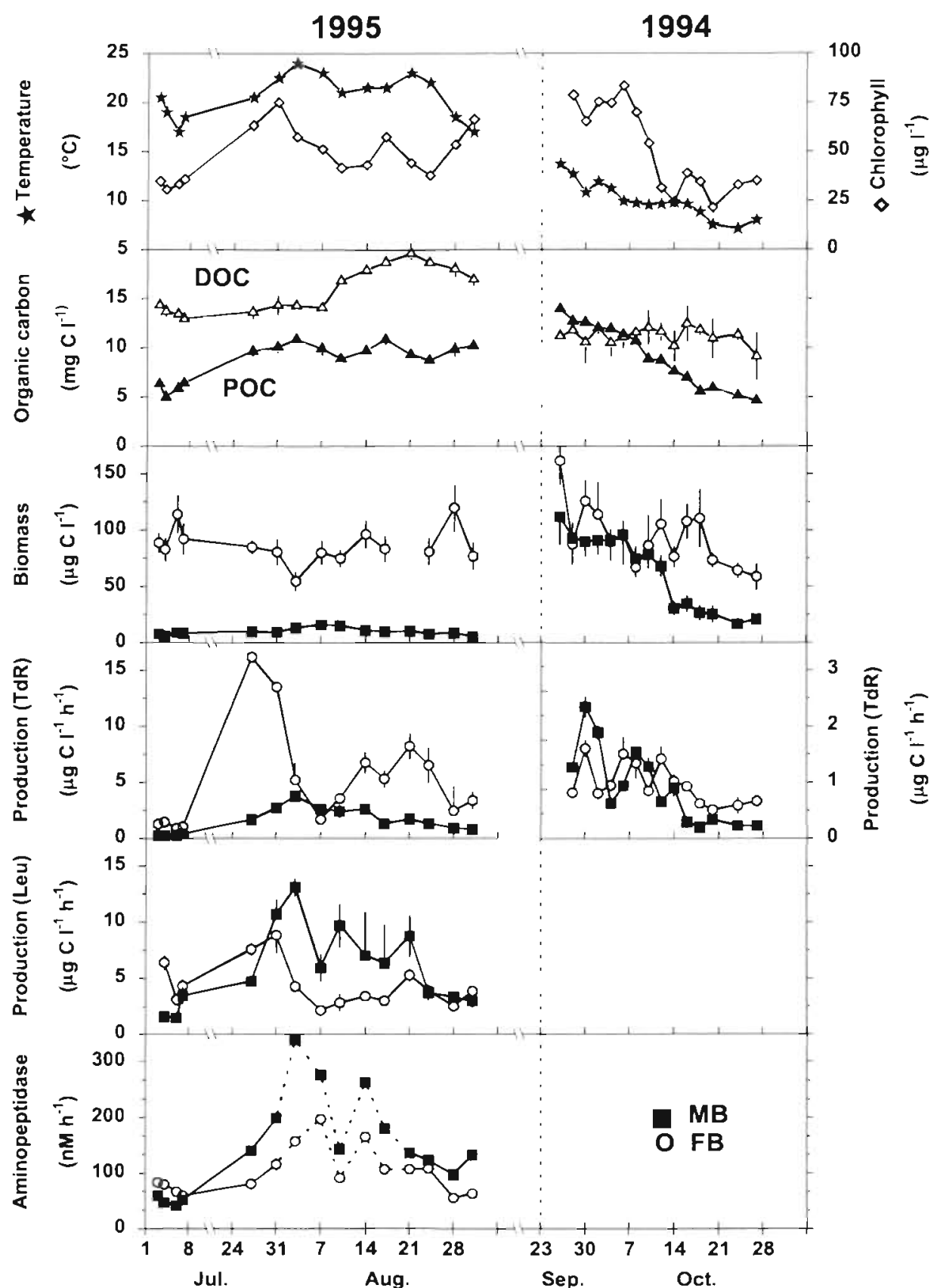

FB biomass was rather constant and ranged mostly

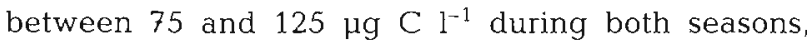
although it tended to decrease during autumn $\left(r_{\mathrm{s}}=\right.$ $-0.57, \mathrm{p}=0.040, \mathrm{n}=14$ ) (Fig. 2). During summer FB

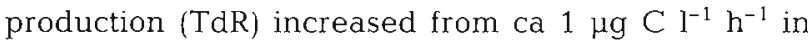
early July with 2 peak values on July 27 at $16.2 \mu \mathrm{g} \mathrm{C} \mathrm{l^{-1 }}$ $\mathrm{h}^{-1}$ and on August 21 at $8.2 \mu \mathrm{g} \mathrm{C} \mathrm{l}^{-1} \mathrm{~h}^{-1}$, but declined

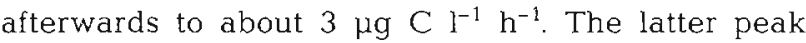
of production followed the dynamics of DOC from August 7 . During autumn FB production (TdR) fluctuated between 0.91 and 1.82 , but decreased to $0.6 \mu \mathrm{g}$ 
Table 2. Relative contribution of Microcystis-assoctated bacteria (MB, size fraction $>20 \mu m$ ) in Frederiksborg Slotss $\varnothing$ during summer 1995 and autumn 1994. Values are calculated as $\mathrm{MB} /(\mathrm{MB}+\mathrm{FB}) \times 100 \%$ and listed as average \pm standard deviation with the range in parentheses

\begin{tabular}{|c|c|c|c|c|c|}
\hline \multirow[t]{2}{*}{ Period } & \multirow{2}{*}{$\begin{array}{c}\text { Abundance } \\
(\%)\end{array}$} & \multirow{2}{*}{$\begin{array}{c}\text { Biomass } \\
(\%)\end{array}$} & \multicolumn{2}{|c|}{ Production } & \multirow{2}{*}{$\begin{array}{l}\text { Potential aminopepti- } \\
\text { dase activity }(\%)^{\mathrm{a}}\end{array}$} \\
\hline & & & Thymidine $(\%)$ & Leucine $(\%)$ & \\
\hline Summer 1995 & $\begin{array}{c}8 \pm 3 \\
(5-15)\end{array}$ & $\begin{array}{c}10 \pm 4 \\
(6-19)\end{array}$ & $\begin{array}{l}25 \pm 13 \\
(9-61)\end{array}$ & $\begin{array}{l}55 \pm 18 \\
(20-78)\end{array}$ & $\begin{array}{l}53 \pm 12 \\
(37-68)\end{array}$ \\
\hline Autumn 1994 & $\begin{array}{l}32 \pm 11 \\
(15-46)\end{array}$ & $\begin{array}{l}37 \pm 12 \\
(19-52)\end{array}$ & $\begin{array}{l}43 \pm 16 \\
(24-70)\end{array}$ & & \\
\hline \multicolumn{5}{|c|}{${ }^{d}$ Data from August 3 to 17 are excluded } & \\
\hline
\end{tabular}

$\mathrm{C}^{-1} \mathrm{~h}^{-1}$ in late October, significantly correlated with the production of $\mathrm{MB}$ (Table 1).

Consistently, MB comprised a smaller fraction of total abundance or biomass as compared to total production and potential aminopeptidase activity, which corresponds to higher specific activities of $M B$ (Table 2). During summer 1995 cell growth rates of MB were significantly higher than those of $\mathrm{FB}(\mathrm{p}<0.002)$, in contrast to autumn 1994 where averages ( \pm standard deviation) of $0.40 \pm 0.19$ and $0.30 \pm 0.10 \mathrm{~d}^{-1}$ for $\mathrm{MB}$ and $F B$, respectively, were not statistically different $i p=$ 0.069). Further, specific aminopeptidase activity of $M B$ was significantly higher than that of $\mathrm{FB}$ when tested nonparametrically (TdR: $\mathrm{p}=0.006, \mathrm{n}=10$; Leu: $\mathrm{p}=$ $0.018, \mathrm{n}=9)$ and values of $\mathrm{MB}$ and $\mathrm{FB}$ averaged $1.60 \pm$ 0.67 and $0.41 \pm 0.32 \mathrm{~mol}$ Leu-MCA hydrolysed per mol $C$ produced (TdR), respectively, and $0.027 \pm 0.010$ and $0.018 \pm 0.006 \mathrm{~mol}$ Leu-MCA hydrolysed per mol C produced (Leu), respectively, assuming negligible algal leucine incorporation.

Production derived from the thymidine and leucine methods correlated significantly for $\mathrm{MB}\left(\mathrm{r}_{\mathrm{s}}=0.90, \mathrm{p}=\right.$ $0.001, \mathrm{n}=14$ ), as did summed rates ( $\mathrm{MB}+\mathrm{FB}$ ), representing total production from each method $\left(r_{5}=0.78\right.$ $\mathrm{p}=0.005, \mathrm{n}=14$ ) (Fig. 3). The molar ratios of incorporated Leu and TdR (Leu:TdR ratio) were consistently larger for $\mathrm{MB}$ than for $\mathrm{FB}$ and averaged 23.2 and 3.81 , respectively, which reflects that $M B$ produce more biomass per cell division than FB. This result is qualitatively in accordance with the higher cell volumes mea-

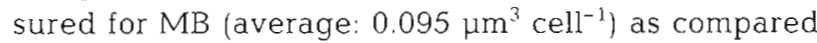
to $\mathrm{FB}\left(0.071 \mathrm{\mu m}^{3}\right.$ cell $\left.^{-1}\right)$, but the small difference in volumes is insufficient to explain the larger difference in Leu:TdR molar ratios based on reported linear or exponential relationships between cell volume and cell carbon (Simon \& Azam 1989, Theil-Nielsen \& Søndergaard in press). In 2 later experiments, we tested whether this difference reflected that samples were extracted for $1 \mathrm{~h}$ with $5 \%$ TCA before fractionation. It was the hypothesis that macromolecules labelled with either ${ }^{3} \mathrm{H}$-Leu or ${ }^{3} \mathrm{H}$-TdR distributed differently upon precipitation with TCA. Less radioactivity was mea- sured in the $<20 \mu \mathrm{m}$ size fraction after TCA extraction and decreases amounted to 6.5 and $7.7 \%$ for $\mathrm{TdR}$ and 2.1 and $6.7 \%$ for Leu, but within the limits of the standard deviations. The measures are biased because recovered radiolabel averaged only $75 \pm 14.5 \%$ (range 58 to $92 \%$ ) of unfractionated totals (Fig. 4). Anyway, Leu:TdR ratios in $<20 \mu \mathrm{m}$ size fractions were unaffected by the order of TCA-extraction and fractionation (Expt 1: $15.8 \pm 0.34$; Expt 2: $10.8 \pm 0.34$ ), whereas Leu:TdR ratios in $>20 \mu \mathrm{m}$ size fractions were higher and more variable without any consistent trends. On this basis we conclude that the relative disagreement between Leu:TdR ratios and cell volumes measured during summer are robust to methodological errors. Taken at face values, calculated growth rates indicate that the leucine method overestimated the MB produc-

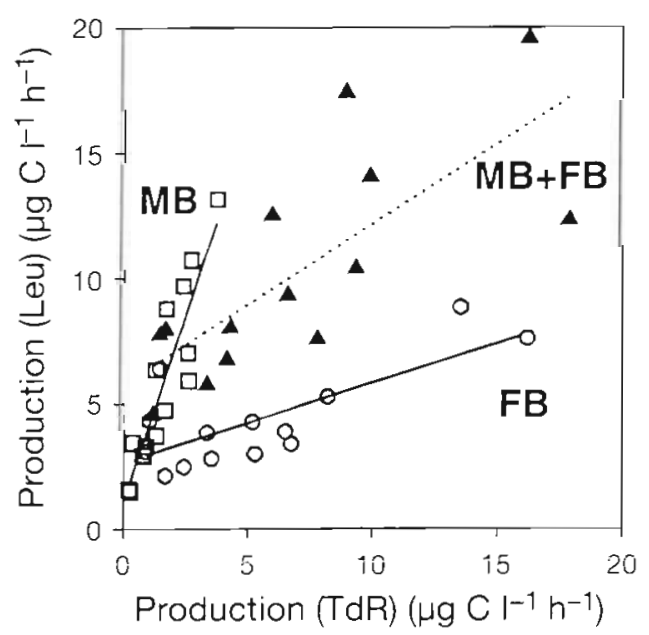

Fig. 3. Relationship between bacterial production of biomass estimated with the thymidine (TdR) and leucine (Leu) methods, Frederiksborg Slotssø, summer 1995. (a) Bacteria attached to Microcystis ( $\mathrm{MB},>20 \mu \mathrm{m}$ mesh-width size fraction), (o) mainly free-living bacteria ( $F B,<20 \mu \mathrm{m}$ mesh-width size fraction) and (4) summed rates $(\mathrm{MB}+\mathrm{FB})$, corresponding to unfractionated samples. Lines are fitted with linear regressions: $M B$, Leu $=$ $\mathrm{TdR} \times 2.992+1.052\left(\mathrm{r}^{2}=0.81\right)_{;} \mathrm{FB}, \mathrm{Leu}=\mathrm{TdR} \times 0.315+2.646$ $\left(r^{2}=0.53\right) ;$ and $(M B+F B)$, Leu $=T d R \times 0.641+5.735\left(r^{2}=0.56\right)$ 


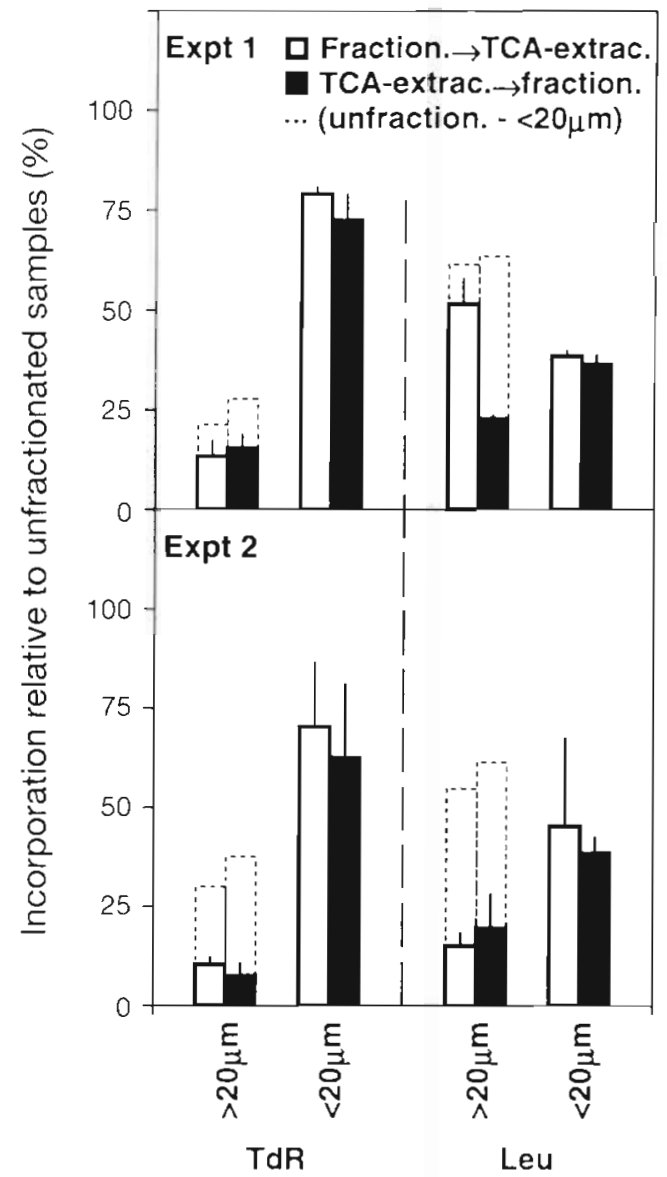

Fig. 4. Two experiments showing the distribution of TdR and Leu incorporation in samples fractionated with $20 \mu \mathrm{m}$ meshwidth nets either before (open bars) or after (solid bars) $1 \mathrm{~h}$ extraction with 5\% TCA. Unrecovered radiolabel (dotted bars) are added to bars of $>20 \mu \mathrm{m}$ size fractions

tion. Growth rates of $\mathrm{MB}$ averaged $3.2 \pm 1.8 \mathrm{~d}^{-1}$ (TdR) and the unrealistically high value of $10.6 \pm 4.1 \mathrm{~d}^{-1}$ (Leu), whereas estimates of FB agreed better, averaging $1.2 \pm 0.62^{-1}\left(\mathrm{TdR}\right.$ ) and $1.4 \pm 1.3 \mathrm{~d}^{-1}$ (Leu). However this conclusion is sensitive to both inaccuracies of the conversion factors used and storage effects on estimates of bacterial biomass and cell volume (Turley \& Hughes 1992, Gundersen et al. 1996).

\section{DISCUSSION}

$\mathrm{MB}$ are not easily segregated from the FB. Manual collection of Microcystis colonies with micropipette is a specific but laborious method (Boström et al. 1989 Brunberg 1993). Our purpose, to study short-term dynamics of $\mathrm{MB}$ and $\mathrm{FB}$ in abundance, production and aminopeptidase activity, demanded a rapid segregation procedure, but the definition that $20 \mu \mathrm{m}$ mesh- width nets retained $\mathrm{MB}$ is not accurate: bacteria attached to large non-Microcystis particles were also included in the $>20 \mu \mathrm{m}$ size fraction and loss of MB to the filtrate during fractionation cannot be neglected (Bern 1987). We did not attempt to quantify these methodological errors, but point out that they work in opposite directions regarding the accuracy of $\mathrm{MB}$ in abundance and activity. We consider that our method gives a fair description of the dynamics of $\mathrm{MB}$. In a parallel study during summer 1995, particles retained by $3 \mu \mathrm{m}$ pore-size filters were predominated in number by transparent exopolymer particles (TEP, of maximum length 3.2 to $162.0 \mu \mathrm{m})$, colonized by $7 \%$ of the total bacterial community (Worm \& Søndergaard in press). The relative contribution of $\mathrm{MB}$ was comparable (Table 2), but it is unlikely that TEP-bacteria dominated bacterial abundance in the $>20 \mu \mathrm{m}$ size fraction regularly, because TEP is deformable and less efficiently retained by $20 \mu \mathrm{m}$ mesh-width nets compared to Microcystis colonies.

Leucine incorporation was included in the sampling programme as an independent supplement to the thymidine method to reflect bacterial growth in terms of both biomass (Leu) and cells (TdR). Previous studies with the leucine method have used maximally $100 \mathrm{nM}$ leucine. We incubated at $600 \mathrm{nM}$ leucine, because the kinetic experiments clearly demonstrated that more than $200 \mathrm{nM}$ leucine was needed to approximate the saturation level, in agreement with previous kinetic studies in eutrophic systems (Jørgensen 1992, Riemann \& Azam 1992, van Looij \& Riemann 1993). At saturation level, intracellular isotope dilution of incorporated radiolabel is minimized and independent of affinity, which per se optimizes the coupling to bacterial production. However, high concentrations of leucine increase the risk that bacterial growth is stimulated and/or algae incorporate leucine. Indirect evidence of minor algal leucine incorporation at $600 \mathrm{nM}$ includes that the kinetics of leucine incorporation was hyperbolically rather than linearly related to the respective concentrations, thus indicating the predominance of bacterial leucine incorporation by high affinity uptake systems rather than algal low affinity uptake systems and/or passive diffusion. In addition, incorporated leucine retained on $20 \mu \mathrm{m}$ mesh-width nets (algal fraction) was highly significantly related to thymidine incorporation $\left(\mathrm{r}_{\mathrm{s}}=0.90, \mathrm{p}=0.001, \mathrm{n}=14\right.$ ) and thymidine at $20 \mathrm{nM}$ is neither expected to stimulate bacterial growth nor to be taken up by algae (Bern 1985) (Fig. 3). The significant correlation between summed rates of thymidine and leucine derived production agrees with previous findings (Kirchman 1992, Servais 1992, Simon 1994). Based on these arguments bacterial production was calculated from leucine incorporation at $600 \mathrm{nM}$ using a conversion factor, where 
overall bacterial carbon production is calculated from the direct incorporation of exogenous radiolabelled leucine into bacterial proteins, a constant ratio between leucine in bacterial proteins and overall cell carbon and a 2 -fold intracellular isotopic dilution (Simon \& Azam 1989). Whether these presumptions are fulfilled for $\mathrm{MB}$, including a quantification of algal leucine incorporation, are difficult to measure, because $\mathrm{MB}$ cells then have to be separated from cells and mucilage of Microcystis. The unrealistically high growth rates of $\mathrm{MB}$, as calculated from leucine incorporation (mean $10.6 \mathrm{~d}^{-1}$ ), indicate significant algal incorporation and speaks in favour of the thymidine method, but we emphasize that the conclusion is dependent on our choices of conversion factors. The volume to carbon conversion factor is in the lower range reported (Theil-Nielsen \& Sondergaard in press) and lower leucine conversion factors of 0.900 and $1.080 \mathrm{~kg} \mathrm{C} \mathrm{mol}^{-1}$ have been reported (Servais \& Garnier 1993, Servais \& Lavandier 1993). Increasing the volume to carbon conversion factor and decreasing that of leucine improves the balance between estimates of production for $\mathrm{MB}$ at the expense of $\mathrm{FB}$. The conversion factor for thymidine incorporation was determined in the studied lake (Smits \& Riemann 1988) and corresponds to values often found in other systems. Another possibility for biased growth rate calculations is that the storage of samples with glutaraldehyde for several weeks may have reduced the estimates of bacterial abundance and mean cell carbon (Turley \& Hughes 1992, Gundersen et al. 1996), which leads to overestimated growth rates and underestimated carbon content and biomass of DAPI-stained bacteria. However, tight correlation between bacterial biomass and production indicate that effects due to storage were similarly distributed between the samples. Accordingly, we have no obvious reasons to reject relative differences in either bacterial biomass or specific activities, although both parameters are probably somewhat biased.

During summer 1995, MB averaged only $10 \%$ of total bacterial biomass, but due to the high specific activity $\mathrm{MB}$ contributed on average either $25 \%$ ( $\mathrm{TdR}$ ) or $55 \%$ (Leu) of total bacterial production. MB also showed a high hydrolytic capacity and contributed on average $53 \%$ of the total potential aminopeptidase activity (Table 2). Specific aminopeptidase activity of $\mathrm{MB}$ also exceeded that of FB significantly. In autumn the colonization of Microcystis was more intense and peak values of $\mathrm{MB}$ biomass and production exceeded FB episodically. However, the relative contribution of $M B$ declined to about 15 to $20 \%$ in late October, as Microcystis gradually disappeared from the surface water (Fig. 2). All measures of bacterial activity thus point to an important ecological role of $\mathrm{MB}$ in bacterial carbon dynamics during blooms of Microcystis (Table 2), as evident from previous studies (Bell et al. 1983, Konda 1984, Brumberg 1993).

Obviously, Microcystis colonies occupied a negligible volume of the bulk water. Nevertheless, the abundance and activity of $\mathrm{MB}$ were indeed significant, which designates this microenvironment for heterotrophic bacteria as an intense 'hotspot'. Accordingly, bacterial activity of pelagic waters may be heterogeneously distributed on the macroscopic scale during blooms of Microcystis, as evident for larger particles known as marine or lake snow (Smith et al. 1992, Grossart \& Simon 1993). If the measured growth rates reflect, at least, qualitative differences between actively growing cells, the higher growth rates of $\mathrm{MB}$ during summer indicate that the microenvironment of Microcystis was enriched with labile substrates relative to the surrounding water. In general, high substrate availability selects for low affinity/high capacity uptake systems (Søndergaard \& Middelboe 1995). Consistently, such uptake systems characterized leucine incorporation of MB compared to FB (Fig. 1). The higher specific activity of $\mathrm{MB}$ may reflect the combined effects of (1) higher steady-state concentration of exudates within the mucilage of Microcystis, (2) increased exchange of nutrients with the surrounding water, as $\mathrm{MB}$ move through the water column driven by the density of Microcystis (Thomas \& Walsby 1986), (3) adsorption of labile organic matter to the mucilage of Microcystis (Fletcher 1991), and (4) diversified species composition (Brunberg 1993). During autumn, however, growth conditions were rather similar according to the statistical similarity between measured growth rates. An opposite characterization of $\mathrm{MB}$ was given by Brunberg (1993), who found that thymidine incorporation per cell of MB was below that of $\mathrm{FB}$ in late summer and early autumn. Low mortality, nutrient limitation or accumulated algal metabolites were proposed to sustain MB abundance near 'carrying-capacity', generally characterized by relatively inactive bacteria, long turnover times and low specific growth rates. Most likely, the activity of $\mathrm{MB}$ may be inhibited, if the microenvironment of Microcystis becomes alkaline during photosynthesis, as evident from axenic colonies of Microcystis (Richardson \& Stolzenbach 1995). However, no general pattern about the chemical microenvironment of Microcystis is obvious from the measured growth rates of DAPI-stained bacteria.

$\mathrm{MB}$ production ( $\mathrm{TdR}$ ) ranged from 0.23 to $3.77 \mathrm{\mu g} \mathrm{C}$ $\mathrm{I}^{-1} \mathrm{~h}^{-1}$, whereas the calculated increases in biomass could be accounted for by a maximum of $0.067 \mu \mathrm{g} \mathrm{Cl}^{-1}$ $\mathrm{h}^{-1}$. Therefore, more than $70 \%$ of the $\mathrm{MB}$ production was not recovered as increased biomass, which indicates that most gain of $\mathrm{MB}$, i.e. growth and colonization, balanced the loss from grazing, lysis, sedimenta- 
tion and shedding (Pedrós-Alió \& Brock 1983). We hypothesize that a large fraction of $\mathrm{MB}$ production was shedded to the surrounding water. This characterizes Microcystis as a bacterial 'incubator'. The idea is based on reported low loss rates of Microcystis from sedimentation and grazing during summer (Reynolds 1973, DeMott \& Dhawale 1995). Further, we did not observe any protozoa grazing on MB, and Bern (1987) could not measure any grazing of $\mathrm{MB}$ by mesozooplankton. However, loss of $\mathrm{MB}$ due to viral lysis remains unsolved. In one marine study virus infection was detected in 2 to $37 \%$ of the bacteria associated with particles (Proctor \& Fuhrman 1991). Applying this range to our results, however, shedding of $\mathrm{MB}$ is likely to be an important loss factor. Attached bacteria shedding daughter cells to the surrounding water is evident from studies of biofilm formation (Caldwell et al. 1992), and recognized from various types of natural particles including copepod fecal pellets (Jacobsen \& Azam 1984), marine snow (Azam \& Smith 1991) and diatommucus aggregates retained by $1 \mu \mathrm{m}$ pore-size filters (Smith et al. 1995).

In conclusion, Microcystis offers attachment sites for a very dynamic community of heterotrophic bacteria, which contributes importantly to the carbon metabolism of pelagic bacteria. Up to half of total bacterial production was assigned to this microenvironment during summer and autumn. As Microcystis often dominates the phytoplankton of eutrophic lakes, the pelagic microenvironment of these systems may be considered heterogeneous with intense 'hotspots' of bacterial activity in association with the macroscopic colonies of Microcystis.

Acknowledgements. We appreciate the comments and suggestions by Meinhard Simon and 3 anonymous reviewers. The study was supported by The Danish Natural Sciences Research Council and The Danish Environmental Research Programme

\section{LITERATURE CITED}

Andersen JM, Jacobsen OS (1979) Production and decomposition of organic matter in eutrophic Frederiksborg Slotssø, Denmark. Arch Hydrobiol 85(4):511-542

Azam F, Smith DC (1991) Bacterial influence on the variability in the ocean's biogeochemical state: a mechanistic view. In: Demers $S$ (ed) Particle analysis in oceanography. Springer-Verlag, Berlin, p 213-236

Bell RT, Ahlgren GM, Ahlgren I (1983) Estimating bacterioplankton production by measuring $\left[{ }^{3} \mathrm{H}\right]$ thymidine incorporation in a eutrophic Swedish lake. Appl Environ Microbiol 45(6): 1709-1721

Bern L (1985) Autoradiographic studies of [methyl $\left.-{ }^{3} \mathrm{H}\right]$ thymidine incorporation in a Cyanobacterium (Microcystis wesenbergii)-bacterium association and in selected algae and bacteria. Appl Environ Microbiol 49(1):232-233
Bern L (1987) Zooplankton grazing on [methy] ${ }^{3} \mathrm{H}$ ]thymidinelabelled natural particle assemblages: determination of filtering rates and food selectivity. Freshwat Biol 17(1): $151-159$

Boström B, Petterson AK, Ahlgren I (1989) Seasonal dynamics of a cyanobacteria-dominated microbial community in surface sediment of a shallow, eutrophic lake. Aquat Sci 51(2): $153-178$

Brunberg AK (1993) Microcystis in lake sediments. PhD thesis, Uppsala University

Caldwell DE, Korber DR, Lawrence JR (1992) Confocal laser microscopy and digital image analysis in microbial ecology. Adv Microb Ecol 12:1-67

Christoffersen K, Riemann B, Hansen LR, Klysner A Sorensen HB (1990) Qualitative importance of the microbial loop and plankton community in a eutrophic lake during a bloom of Cyanobacteria. Microb Ecol 20:253-272

DeMott WR, Dhawale S (1995) Inhibition of in vitro protein phosphatase activity in three zooplankton species by microcystin-LR, a toxin from cyanobacteria. Arch Hydrobiol 134(4):417-424

Fletcher $M$ (1991) The physiological activity of bacteria attached to solid surfaces. Adv Microb Physiol 32:53-85

Fuhrman JA, Azam F (1980) Bacterioplankton secondary production estimates for coastal waters of British Columbia Antarctica and California. Appl Environ Microbiol 39 $1085-1095$

Grossart HP, Simon M (1993) Limnetic macroscopic organic aggregates (lake snow): occurrence, characteristics, and microbial dynamics in Lake Constance. Limnol Oceanogr 38(3):532-546

Gundersen K, Bratbak G, Heldal M (1996) Factors influencing the loss of bacteria in preserved seawater samples. Mar Ecol Prog Ser 137:305-310

Herndl GJ (1988) Ecology of amorphous aggregations (marine snow) in the Northern Adriatic Sea. II. Microbial density and activity in marine snow and its implication to overall pelagic processes. Mar Ecol Prog Ser 48:265-275

Hollibaugh JT, Wong PS (1992) Ethanol-extractable substrate pools and the incorporation of thymidine, L-leucine, and other substrates by bacterioplankton. Can J Microbiol 38 $605-613$

Hoppe $\mathrm{H}$ (1993) Use of flourogenic model substrates for extracellular enzyme activity (EEA) measurement of bacteria. In: Kemp PF, Sherr BF, Sherr EB, Cole IJ (eds) Handbook of methods in aquatic microbial ecology. Lewis Publ, Boca Raton, p 423-431

Jacobsen TR, Azam F (1984) Role of bacteria in copepod fecal pellet decomposition: colonization, growth rates and mineralization. Bull Mar Sci 35(3):495-502

Jespersen AM, Christoffersen K (1987) Measurements of chlorophyll-a from phytoplankton using ethanol as extraction solvent. Arch Hydrobiol 109(3):445-454

Jargensen NOG (1992) Incorporation of $\left[{ }^{3} \mathrm{H}\right]$ leucine and $\left[{ }^{3} \mathrm{H}\right]$ valine into protein of freshwater bacteria: field applications. Appl Environ Microbiol 58(11):3647-3653

Jürgens K, Güde $H$ (1994) The potential importance of grazing-resistant bacteria in planktonic systems. Mar Ecol Prog Ser 112:169-188

Kirchman DL (1992) Incorporation of thymidine and leucine in the subarctic Pacific: application to estimating bacterial production. Mar Ecol Prog Ser 82:301-309

Kirchman DL (1993) Particulate detritus and bacteria in marine environments In: Ford TE (ed) Aquatic microbiology -an ecological approach. Blackwell, Oxford, p 321-341

Kirchman D, K'Nees E, Hodson R (1985) Leucine incorpora- 
tion and its potential as a measure of protein synthesis by bacteria in natural aquatic systems. Appl Environ Microbiol 49(3):599-607

Konda I (1984) Seasonal variations in four bacterial size fractions from a hypertrophic pond in Tokyo, Japan. Int Rev Ges Hydrobiol 69(6):843-858

Pedrós-Alió C, Brock TD (1983) The importance of attachment to particles for planktonic bacteria. Arch Hydrobiol 98(3):354-379

Porter KG, Feig YS (1980) The use of DAPI for identifying and counting aquatic microflora. Limnol Oceanogr 25(5): 943-948

Proctor LM, Fuhrman JA (1991). Roles of viral infection in organic particle flux. Mar Ecol Prog Ser 69:133-142

Reynolds CS (1973) Growth and buoyancy of Microcystis aeruginosa Kütz. emend. Elenkin in a shallow eutrophic lake. Proc R Soc Lond B 184:29-50

Reynolds CS, Rogers DA (1976) Seasonal variations in the vertical distribution and buoyancy of Microcystis aeruginosa Kütz. Emend. Elenkin in Rostherne Mere, England Hydrobiologia 48(1):17-23

Richardson LL, Stolzenbach KD (1995) Phytoplankton cell size and the development of microenvironments. FEMS Microbiol Ecol 16:185-192

Riemann B, Azam F (1992) Measurements of bacterial protein synthesis in aquatic environments by means of leucine incorporation. Mar Microb Food Webs 6(2):91-105

Servais P (1992) Bacterial production measured by ${ }^{3} \mathrm{H}$-thymidine and ${ }^{3} \mathrm{H}$-leucine incorporation in various aquatic ecosystems. Arch Hydrobiol Beih Ergeb Limnol 37:73-81

Servais P, Garnier J (1993) Contribution of heterotrophic bacterial production to the carbon budget of the River Seine (France). Microb Ecol 25:19-33

Servais $P$, Lavandier P (1993) Cohérence des productions bactériennes estimées à partir de l'incorporation de ${ }^{3} \mathrm{H}$-thymidine et de ${ }^{3} \mathrm{H}$-leucine dans les eaux douces naturelles. CR Acad Sci Ser III Sci Vie 316:642-646

Simon M (1994) Diel variability of bacterioplankton biomass production and cell multiplication in Lake Constance Arch Hydrobiol 130(3):283-302

Simon $M$, Azam F (1989) Protein content and protein synthesis rates of planktonic marine bacteria. Mar Ecol Prog Ser 51:201-213

Editorial responsibility: John Dolan,

Villefranche-sur-Mer, France
Smith DC, Simon M, Alldredge AL, Azam F (1992) Intense hydrolytic enzyme activity on marine aggregates and implications for rapid particle dissolution. Nature 359: $139-142$

Smith DC, Steward GF, Long RA, Azam F (1995) Bacterial mediation of carbon fluxes during a diatom bloom in a mesocosm. Deep Sea Res 42(1):75-97

Smits JD, Riemann B (1988) Calculation of cell production from $\left[{ }^{3} \mathrm{H}\right]$ thymidine incorporation with freshwater bacteria. Appl Environ Microbiol 54(9):2213-2219

Sondergaard M, Middelboe M (1993) Measurements of particulate organic carbon: a note on the use of glass fiber (GF/F) and Anodisc filters. Arch Hydrobiol 127(2):73-85

Sondergaard M, Middelboe M (1995) A cross-system analysis of labile dissolved organic carbon. Mar Ecol Prog Ser 118: 283-294

Theil-Nielsen J, Søndergaard M (in press) A note on bacterial carbon biomass calculated from biovolumes. Arch Hydrobiol

Thomas RH, Walsby AE (1986) The effect of temperature on recovery of buoyancy by Microcystis. J Gen Microbiol 132: $1665-1672$

Turley CM, Hughes DJ (1992) Effects of storage on direct estimates of bacterial numbers of preserved seawater samples. Deep Sea Res 39(3/4):375-394

van Looij A, Riemann B (1993) Measurements of bacterial production in coastal marine environments using leucine: application of a kinetic approach to correct for isotope dilution. Mar Ecol Prog Ser 102:97-104

Velji MI, Albright LJ (1993) Improved samples preparation for enumeration of aggregated aquatic substrate bacteria. In: Kemp PF, Sherr BF, Sherr EB, Cole JJ (eds) Handbook of methods in aquatic microbial ecology. Lewis Publ, Boca Raton, p 139-142

Whitton BA (1973) Interactions with other organisms. In: Carr NG, Whitton BA (eds) The biology of blue-green algae. Blackwell, Oxford, p 415-433

Wicks RJ, Robarts RD (1988) Ethanol extraction requirement for purification of protein labeled with $\left[{ }^{3} \mathrm{H}\right]$ leucine in aquatic bacterial production studies. Appl Environ Microbiol $54(12): 3191-3193$

Worm J, Sondergaard M (in press) Alcian Blue stained particles in a eutrophic lake. J Plankton Res

Submitted: November 15, 1996; Accepted: June 16, 1997

Proofs received from author(s): September 19, 1997 